\title{
Stimulation of development of Cucumis sativus L. plants by low concentration of aluminium in vitro conditions
}

\author{
MARIA SZYMAŃSKA, JOLANTA MOLAS \\ Department of Plant Physiology, University of Agriculture, \\ Akademicka 15, 20-950 Lublin, Poland
}

(Received: September 13, 1995)

\begin{abstract}
A b stract
The culture of cucumber plants Cucumis sativus L. Wisconsin cultivar, from seeds and leaf explants, were carried out on the basic medium of Murashige and Skoog in vitro conditions. In the culture set from the leaf explants the MS medium was supplemented with IAA $\left(0.5 \mathrm{mg} / \mathrm{dm}^{3}\right)$ and BAP $\left(2 \mathrm{mg} / \mathrm{dm}^{3}\right)$. Aluminium (as $\mathrm{AlCl}_{3}$ ) was added to the media in concentration of $1 \mathrm{mg} / \mathrm{dm}^{3}$. The media $\mathrm{pH}$ was adjusted to 6.2 or 4.2 . In seedling culture, aluminium substantially stimulated the growth and development of the root system while a shoot to a small degree only (it advanced leaf formation mainly), causing no morphological and developmental anomalies. In the culture from the leaf explants Al induced the process of rhizogenesis which did not take place on the media without Al. It also stimulated a shoot morphogenesis. After 8 weeks of culture, $32 \%$ leaf explants formed plants with short shoots $(2-3.5 \mathrm{~cm})$, long ones $(5.5-7 \mathrm{~cm})$ and with long but poorly branched root system. In the acid conditions $(\mathrm{pH}$ 4.2), the effect o $\mathrm{Al}$ on plant growth was lower than on the media with pH 6.2. Also a number of regenerated explants with comparable direction of differentiation won a fewer in low $\mathrm{pH}$.
\end{abstract}

\section{INTRODUCTION}

There are only fragmentary data showing that aluminium could be indispensable for the development of some plant species, mainly hydrophilous, among others Glyceria aquatica and Juncus effusus (S z k o $1 \mathrm{n}$ i k, 1980). Its physiological function as a microelement has not been confirmed so far, nevertheless, it is numbered among the elements which are likely to perform it beside $\mathrm{Ni}, \mathrm{Rb}, \mathrm{Sr}$, and $\mathrm{Ti}$ (P e n d i a s- K a b a t a and Pe nd i a s, 1993). The Al salts added to a medium at low concentration stimulate the growth of many plant species, in particular tropical 
plants as well as the plants cultivated in the moderate climatic zone (B o r k o w s k a, 1988, 1991; Ś l a s k i, 1992).

The mechanism of stimulating action of $\mathrm{Al}$ ions on the growth is not known ant it has been examined to a considerably smaller extent than a mechanism of $\mathrm{Al}$ toxicity. It is assumed that $\mathrm{Al}$ exerts stimulating effect upon the plant growth indirectly, its presence in the soil causes the increase of availability or uptake of such elements like: Fe and P, while it limits the uptake of excessive amount of $\mathrm{Cu}$ and $\mathrm{Mn}$ (F o y et al., 1978; F o y, 1984). The $\mathrm{Al}$ ions could also induce a favorable changes in the distribution of endogenous growth regulators in root cells as well as stimulation of mitotic activity and elongation of the root apical meristemic cells (B e $\mathrm{n} n$ e $\mathrm{t}$ et al., 1985; B e n n e ta and B re e n, 1991; F o y, 1988).

Regarding the previously established fact that $\mathrm{Al}$ ions in low concentration $1 \mathrm{mg} / \mathrm{dm}^{3}$ have stimulated effectively the growth of cucumber seedling roots $\mathrm{cv}$. Wisconsin in water culture (the data unpublished), we have decided to examine whether they also show a stimulating effect on the plant differentiation and growth in in vitro conditions.

\section{MATERIAL AND METHODS}

\section{Experiment 1}

The cucumber seeds (Cucumis sativus L.) Wisconsin cultivar after $10 \mathrm{~min}$. sterilization in $0.04 \% \mathrm{HgCl}_{2}$ were placed on $\mathrm{MS}$ medium ( $\mathrm{M} \mathrm{u} \mathrm{r}$ a s h i g e and $\mathrm{S} \mathrm{k} \mathrm{o} \mathrm{o} \mathrm{g,} \mathrm{1962)} \mathrm{of} \mathrm{pH} 6.2$ or 4.2 (controls). The $\mathrm{Al}$ (as $\mathrm{AlCl}_{3}$ ) was added to the basic MS medium in concentration of $1 \mathrm{mg} / \mathrm{dm}^{3}$. The $\mathrm{pH}$ of media with $\mathrm{Al}$ was adjusted to 6.2 or 4.2 . After 8 and 16 days of culturing, the number of regenerated plants and their morphometrical parameters like: length of root system, length of hypocotyl and dry matter content were established. The description of their morphological traits was also performed.

\section{Experiment 2}

The leaf explants were obtained from young cucumber plants $\mathrm{cv}$. Wisconsin grown under sterile conditions. Afterwards they were placed on MS medium of $\mathrm{pH}$ 6.2 or 4.2 . The media were supplemented with IAA (3-indoleacetic acid) 0.5 $\mathrm{mg} / \mathrm{dm}^{3}$, and BAP (benzylaminopurine) $2 \mathrm{mg} / \mathrm{dm}^{3}$. Aluminium was added as $\mathrm{AlCl}_{3}$ at concentration of $1 \mathrm{mg} / \mathrm{dm}^{3}$. In the course of culture, there were observations on the time of roots and/or shoots emerging. After 2, 4, 6, and 8 weeks of culture, a number of formed shoots, roots and rooted plants determined. Beside, a description of their morphological traits was made up.

The experiments 1 and 2 were carried out in 4 series. Each series contained 20 cultures. 


\section{RESULTS}

\section{Experiment 1}

Aluminium at the concentration of $1 \mathrm{mg} / \mathrm{dm} 3$ stimulated seedling growth in both $\mathrm{pH}$ value of media. In the early stage of seedlings development $\mathrm{Al}$ stimulated the main root elongation (Tab. 1, Fig. 1). Later it stimulated the differentiation and elongation of lateral roots of the subsequent raws (Fig. 2). The $\mathrm{Al}$ ions also stimulated the hypocotyl growth during a seedling development, however only in the conditions of pH 6.2 (Tab. 1, Fig. 1). Al also slightly promoted the differentiation and growth of leaves. The 16 days Al-treated seedlings on the media of both $\mathrm{pH} 4.2$ and 6.2 showed a well formed root system with considerably higher number of lateral roots and perhaps more developed leaves as compared to the control plants (Fig. 2).

The roots of plants grown on the media with $\mathrm{Al}$ were macroscopically thicker than control plant roots and demonstrated a higher level of turgoscence. During the juvenile as well as vegetative development periods cucumber plants did not show any developmental and morphological anomalies. The plants manifested high salubrity, mechanical strength and resistance to the overdried medium. Aluminium has not induced any visible increase of seedling number, nevertheless a growing tendency occurred in both media with different $\mathrm{pH}$ (Tab. 1). In the series with Al there was recorded a distinctly stimulated plant growth rate, of root particular, as well as their biomass content (Tab. 1).

Generally, in the acid conditions ( $\mathrm{pH} 4.2$ ) less plants developed in both control and $\mathrm{Al}$ treatments. The growth rate of plants demonstrated less vigour established on the basis of root and hypocotyl length as well as on the measurement of dry mass content of these organs.

$\mathrm{T}$ a b l e 1

The effect of low concentration of $\mathrm{Al}$ on the growth rate of cucumber seedlings obtained from seeds

\begin{tabular}{|l|c|c|c|c|c|c|c|c|}
\hline \multirow{2}{*}{ Parameters } & \multicolumn{4}{c|}{ Medium of pH 4.2 } & \multicolumn{3}{c|}{ Medium of pH 6.2 } \\
\cline { 2 - 9 } & \multicolumn{2}{|c|}{ control } & \multicolumn{2}{c|}{ with Al } & \multicolumn{2}{c|}{ control } & \multicolumn{2}{c|}{ with Al } \\
\cline { 2 - 9 } & $8^{*}$ & $16^{*}$ & $8^{*}$ & $16^{*}$ & $8^{*}$ & $16^{*}$ & $8^{*}$ & $16^{*}$ \\
\hline Hypocotyl & 3.27 & 4.65 & 4.36 & 5.31 & 3.15 & 4.62 & 2.85 & 4.71 \\
length (cm) & \pm 0.46 & \pm 0.70 & \pm 0.31 & \pm 0.29 & \pm 0.42 & \pm 0.57 & \pm 0.28 & \pm 0.36 \\
Root & 4.81 & 11.65 & 7.23 & 12.32 & 4.65 & 9.85 & 5.17 & 9.27 \\
length (cm) & \pm 0.61 & \pm 1.07 & \pm 0.92 & \pm 0.85 & \pm 1.12 & \pm 1.32 & \pm 0.93 & \pm 1.34 \\
Dry weight of seed- & 107.60 & 217.65 & 121.30 & 276.45 & 86.40 & 178.90 & 87.25 & 221.50 \\
lings (mg per seedling) & \pm 17.2 & \pm 31.9 & \pm 14.5 & \pm 29.8 & \pm 12.1 & \pm 23.4 & \pm 14.3 & \pm 36.2 \\
Dry weight of roots & 8.10 & 32.70 & 13.20 & 53.10 & 6.80 & 24.85 & 7.10 & 36.80 \\
(mg per plant) & \pm 1.33 & \pm 2.07 & \pm 1.46 & \pm 3.05 & \pm 1.72 & \pm 3.12 & \pm 1.62 & \pm 3.27 \\
Percentage of obtained & 46.5 & 68.2 & 58.0 & 71.5 & 40.6 & 62.5 & 53.7 & 60.3 \\
seedlings & \pm 3.4 & \pm 4.7 & \pm 4.2 & \pm 5.1 & \pm 4.1 & \pm 4.8 & \pm 3.8 & \pm 2.7 \\
\hline
\end{tabular}

\pm standard deviation

* the data represent the mean of 20 replications after 8 and 16 days of seedling growth 


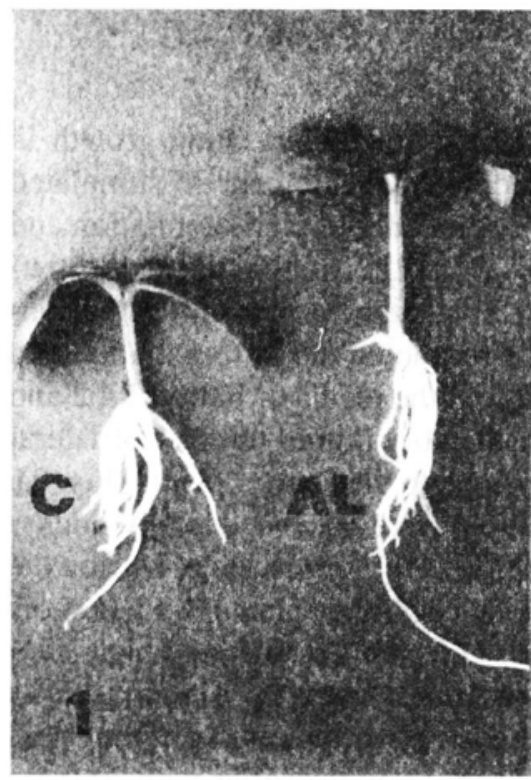

Fig. 1. 8-days old cucumber seedlings obtained from the seeds on the medium of $\mathrm{pH} 6.2$

without $\mathrm{Al} \mathrm{C}$ - control (1), with $\mathrm{Al}(2)$

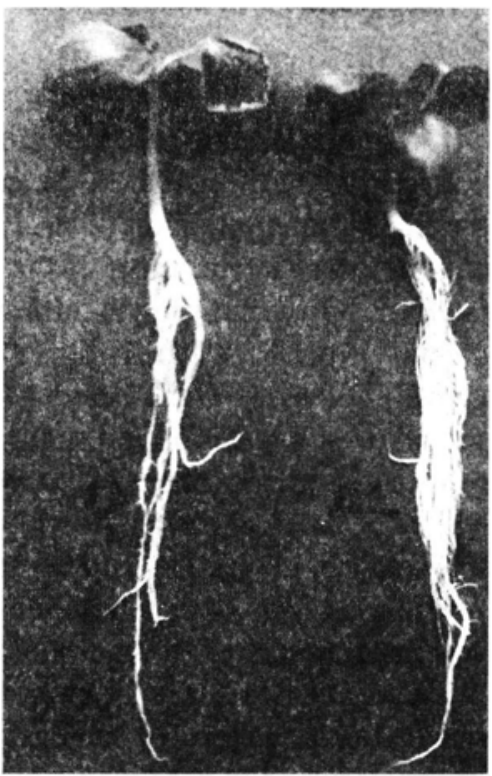

Fig. 2. 16-days old cucumber plants obtained from the seeds on the medium of $\mathrm{pH} 6.2$

without $\mathrm{Al} \mathrm{C}$ - control (1), with $\mathrm{Al}(2)$

\section{Experiment 2}

The leaf explants growing on the MS medium with IAA and BAP regenerated into shoots and did not form any roots at all (Tab. 2). The percentage of the regenrated explants was smaller on the medium of $\mathrm{pH} 4.2$ as compared to that of $\mathrm{pH} 6.2$. After 8 weeks of culture the control seedlings were small and unrooted with shoots of about 2-3.5 cm height and 3-6 leaves (Fig. 3). Aluminium stimulated the process of organogenesis (Tab. 2), induced rhizogenesis and accelerated differentiation as well as elongation of roots and shoots. It should be emphasized that the roots were earier macroscopically identified (after 3 weeks) than shoots (Tab. 2). After 5 weeks of culture the formed roots were already quite well shaped and shoots were of $2.5-5 \mathrm{~cm}$ height $(\mathrm{pH} \mathrm{6.2)}$ and $2-3.3 \mathrm{~cm}(\mathrm{pH} \mathrm{4.2)}$. After 8 weeks of culture majority of Al-treated cucumber plants were well developed (Tab. 2). A few per cent of explants regenerated only into roots.

The Al-treated plants formed both well developed shoots (big shoots) consisting of 3-5 internodes and short shoots (small shoots) (Tab. 3). Both long and short shoots demonstrated long but poorly developed root system. Lateral roots of the first row were short but quite numerous (Fig. 4).

In both cases (control and with $\mathrm{Al}$ ) a direction of plants differentiation was generally similar. There were also differences in readiness of explant cells to regenerate as well as in their growth rate (Tab. 2,3). 
T a b l e 2

The effect of low concentration of $\mathrm{Al}$ on cucumber organogenesis in in vitro conditions

\begin{tabular}{|c|c|c|c|c|c|c|c|c|c|c|c|c|}
\hline \multirow{3}{*}{$\begin{array}{c}\text { After weeks } \\
\text { of culture }\end{array}$} & \multicolumn{6}{|c|}{ Medium of $\mathrm{pH} 6.2$} & \multicolumn{6}{|c|}{ Medium of $\mathrm{pH} 4.2$} \\
\hline & \multicolumn{2}{|c|}{$\begin{array}{l}\text { shoots } \\
(\%)\end{array}$} & \multicolumn{2}{|c|}{$\begin{array}{c}\text { roots } \\
(\%)\end{array}$} & \multicolumn{2}{|c|}{$\begin{array}{c}\text { rooted plants } \\
(\%)\end{array}$} & \multicolumn{2}{|c|}{$\begin{array}{c}\text { shoots } \\
(\%)\end{array}$} & \multicolumn{2}{|c|}{$\begin{array}{l}\text { roots } \\
(\%)\end{array}$} & \multicolumn{2}{|c|}{$\begin{array}{c}\text { rooted plants } \\
(\%)\end{array}$} \\
\hline & control & with $\mathrm{Al}$ & control & with $\mathrm{Al}$ & control & with $\mathrm{Al}$ & control & with $\mathrm{Al}$ & control & with $\mathrm{Al}$ & control & with $\mathrm{Al}$ \\
\hline 2 & 0 & () & 0 & 0 & 0 & 0 & 0 & () & () & 0 & 0 & 0 \\
\hline 4 & 35.0 & 27.0 & 0 & 32.0 & 0 & 10.5 & 16.0 & 12.5 & 0 & 8.0 & () & () \\
\hline 6 & 52.5 & 32.0 & 0 & 35.0 & 0 & 27.5 & 31.5 & 21.0 & () & 22.5 & () & 17.0 \\
\hline 8 & 56.0 & 33.5 & 0 & 36.5 & 0 & 32.0 & 34.0 & 23.5 & 0 & 25.0 & 0 & 21.0 \\
\hline
\end{tabular}

The results represent mean values of 2 series of determination Each series compared 5 cultures

$\mathrm{T}$ a b l e 3

Roots and shoot length of cucumber plants obtained from leaf explants on medium with $\mathrm{Al}$

\begin{tabular}{|c|c|c|c|c|}
\hline \multirow{2}{*}{ Parameters } & \multicolumn{2}{|c|}{ Medium of pH 6.2} & \multicolumn{2}{|c|}{ Medium of $\mathrm{pH} 4.2$} \\
\hline & control & with $\mathrm{Al}$ & control & with $\mathrm{Al}$ \\
\hline Roots length (cm) & 0 & $11.7 \pm 3.07$ & 0 & $6.9 \pm 2.1$ \\
\hline Big shoots length $(\mathrm{cm})$ & $2.57 \pm 0.61$ & $6.18 \pm 1.47$ & $2.08 \pm 0.47$ & $4.35 \pm 1.02$ \\
\hline Small shoots length $(\mathrm{cm})$ & $2.57 \pm 0.61$ & $3.17 \pm 0.63$ & $2.08 \pm 0.47$ & $2.23 \pm 0.46$ \\
\hline
\end{tabular}

\pm standard deviation

The results represent mean values of 2 series of determination

Each series comprises the measures of 10 obtained plants

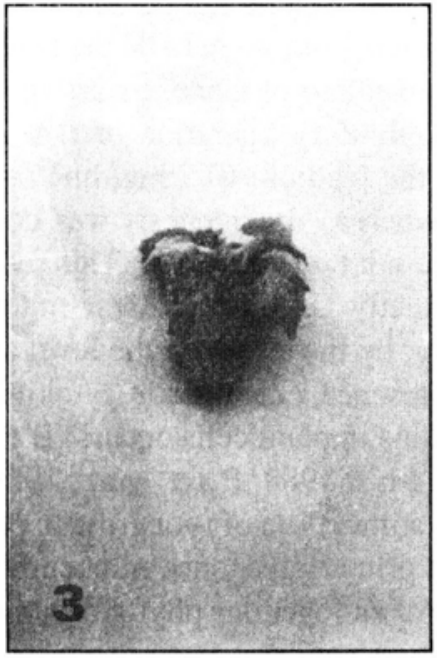

Fig. 3. 8-weeks old leafy cucumber shoot obtained on the medium without aluminium (control)

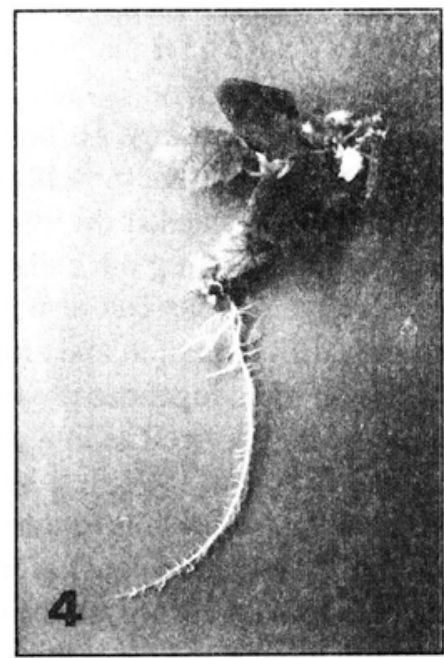

Fig. 4. 8-weeks old cucumber plant obtained from an explant on the medium with $\mathrm{Al}$ at $1 \mathrm{mg} / \mathrm{dm}^{3}$ concentration 


\section{DISCUSSION}

The results of presented investigations indicate that $\mathrm{Al}$ at low concentration substantially stimulated morphogenesis of a root system of Cucumis sativus L. seedlings while to a significantly smaller extent the development of their shoot. It seems that $\mathrm{Al}$ influence upon a shoot has secondary character. This element stimulated not only the elongation growth of the main root but induced also differentiation and stimulated elongation of lateral roots as well as their thickness. Thus, a root system in these plants was morphologically more developed and compact while it did not show any developmental or morphological anomalies. This stimulative influence of $\mathrm{Al}$ upon the root growth was stated also previously in regard to other plant species like: eucalyptus (M u l l e t t e, 1975), rice, tea, sugar beat (F o y, 1983) wheat (A n i o 1, 1984), and maize (B e n n e t et al., 1987).

There are some hypotheses concerning the mechanism of $\mathrm{Al}$ low concentration action B e n n e t and B r e e n (1991) assume that the stimulation of root growth results from $\mathrm{Al}$ influence upon the volume increase of root meristems and the sise of cortical cells. The positive correlation between the point volume and the size of root apical meristem was reported by B a r low and R a t h f e l d e r (1984) as these parameters increase in the presence of low concentrations of $\mathrm{Al}$ ( $\mathrm{B}$ e $\mathrm{n} \mathrm{n}$ e $\mathrm{t}$ and $\mathrm{B}$ re e n, 1991). There were no detailed studies on a reason of root thickness growth of cucumber, nevertheless in can be suggested that, among others, it could be caused by the fast growth of cell size of root tissue what can be in agreament with this hypothesis.

According to another assumption, an $\mathrm{Al}$ stumulative effect can results from a direct influence of $\mathrm{Al}$ ions on the mitotic activity of the root apical meristem (B e n n e t and B r e e n, 1991) and it is well known that $\mathrm{Al}$ ions can be bound with DNA (M a c d o n a ld and Mart in, 1988). Quite interesting seem to be the results dealing with rhizogenesis induction in the micropropagation of Cucumis sativus $\mathrm{L}$. through $\mathrm{Al}$ ions as well as their resistance to the inhibitory operation of BAP. It should be stressed that growth regulators added to the medium $\left(0.5 \mathrm{mg} / \mathrm{dm}^{3}\right.$ IAA, $2 \mathrm{mg} / \mathrm{dm}^{3} \mathrm{BAP}$ ) caused the shoot differentiation, whereas rhizogenesis was completely inhibited (B i g o t and C h l y a h, 1970; Z e n k te le r, 1984). This result suggests that $\mathrm{Al}$ ions can affect the cells either directly i.e. through their mitotic divisions, differentiation and elongation or indirectly, by the effect on the level and distribution of endogenous phytohormones. At Al presence a changes in cytokinins and ABA level, as well as in a polar transport of auxins in plant cells occurs (B e n$\mathrm{n}$ e t and B ree n, 1991; H a s e n ste in and Eva n s, 1988; P a n et al., 1989).

The obtained results (induction of rhizogenesis stimulation of root growth, promotion of mitotic divisions) seems to suggest that a primery response of cucumber plant cells to $\mathrm{Al}$ presence are the changes in the level of endogenous phytohormones, especially auxins and cytokinins.

The question of $\mathrm{Al}$ ions influence on the level and distribution of endogenous phytohormones requires some further detailed investigations. 


\section{REFERENCES}

A $\mathrm{n}$ i o f A., 1984. Induction of aluminium tolerance in wheat seedlings by low doses of aluminium in the nutrient solution. Plant Physiol. 75: 551-555.

B a r l o w P. W., R a th f e ld e r E., 1984. Correlation between the dimensions of different zones of grass root apices, and their implications for morphogenesis and differentiation in roots. Ann. Bot. 53: 249-260.

B e n n e t R. J., B r e e n C. M., F e y M. V., 1985. Aluminium induced changes in the morphology of the quiscent centre, proximal meristem and growth region of the root of Zea mays. S. Afr. J. Bot. 51: 355-362.

B e n n e t R. J., B re e n C. M., F e y M. V., 1987. The effect of aluminium on cap function and root development in Zea mays L. Environ. Exp. Bot. 27: 91-104.

B e n n e t R. J., B r e e n C. M., 1991. The aluminium signal: New dimensions to mechanisms of aluminium tolerance. Plant and Soil 134: 153-166.

B i g o t C., C h l y a h A., 1970. Stimulation precoce du burgeonnement par la benzyladenine sur des explantats foliaires de Begonia rex. Bull. Soc. Bot. Fr. Mem. 117: 48-65.

B ork ow sk a B., 1988. Toksyczność glinu (Al). Wiad. Bot. 32: 157-166.

F o y C. D., Ch a n e y R. L., Wh i t e M. C., 1978. The physiology of metal toxicity in plants. Ann. Rev. Plant Physiol. 29: 511-566.

F o y C. D., 1983. The physiology of plant adaptation to mineral stress. Iowa State J. Res. 57: 353-391.

F o y C. D., 1984. Physiological effect of hydrogen aluminium and manganese toxicities in acid soil. [In:] Adams F. (red). Soil acidity and liming. ASA - CRSSSSA Publ. Madison W.J., 57-96.

F o y C. D., 1988. Plant adaptation to acid. aluminium-toxic soils. Commun. Soil Sci. Plant Annal. 19: 959-987.

H a se n ste in K. H., Eva n s M. L., 1988. Effect of cation on hormone transport in primart roots of Zea mays. Plant Physiol. 86: 89()-894.

M a c d o n a I d T. L., M a rt i n R. B., 1988. Aluminium in biological systems. Trends Biochem. Sci. 13: 15-19.

M u lle t t e K. J., 1975. Stimulation of growth in Eucalyptus due to aluminium. Plant and Soil 42: 495-499.

M u ras h i g e T., S k o o g F., 1962. A revised medium for rapid growth and bioassays with tobacco tissue cultures. Physiol. Plant. 15: 477-497.

P a n W. L., H o p k in s A. G., J a c k s o n W. A., 1989. Aluminium inhibition of shoot lateral branches of Glicine max and reversal by exogenous cytokinin. Olant and Soil 120: 1-9.

Pendi as - K a b a ta A., Pend i as H., 1993. Biogeochemia pierwiastków śladowych. PWN, Warszawa. S z koln i k M., 1980. Mikroelementy w życiu roślin. PWRiL Warszawa.

Ś I a s k i J. J., 1992. Mechanizmy tolerancyjności na toksyczne działanie jonów glinu u roślin wyższych. Wiad. Bot. 36: 31-34.

Z e n k t e I e r M., 1984. Hodowla komórek i tkanek roślinnych. PWN, Warszawa.

\section{Stymulacyjny wpływ niskich koncentracji glinu na rozwój roślin Cucumis sativus $\mathrm{L}$. w warunkach in vitro}

\section{Streszczeni e}

Hodowlę roślin ogórka (Cucumis sativus L.) odmiany Wisconsin z nasion oraz eksplantantów liściowych przeprowadzono na pożywce podstawowej Murashiego i Skooga w warunkach in vitro. W hodowli przeprowadzonej z eksplantantów liściowych pożywkę MS uzupełniono IAA $\left(0,5 \mathrm{mg} / \mathrm{dm}^{3}\right)$ i BAP $\left(2 \mathrm{mg} / \mathrm{dm}^{3}\right)$. Glin $\left(\mathrm{AlCl}_{3}\right)$ dodano do pożywek w stężeniu $1 \mathrm{mg} / \mathrm{dm}^{3}$. Odczyn pożywki doprowadzono do pH 6,2 oraz pH 4,2. W hodowli roślin z nasion glin stymulował wzrost i rozwój systemu korzeniowego, w stopniu minimalnym pędu (głównie przyspieszal formowanie liści), nie powodując przy tym żadnych 
anomalii morfologiczno-rozwojowych. W hodowli przeprowadzonej z eksplantantów liściowych glin indukował proces rizogenezy, który w ogóle nie zachodził na pożywkach bez Al. Stymulował także wzrost i rozwój pędu. Po 8 tygodniach hodowli z $32 \%$ eksplantantów uzyskano rośliny o pędach krótkich $(2-3,5 \mathrm{~cm})$ i o pędach długich $(5,5-7 \mathrm{~cm})$ oraz o długim, lecz słabo rozkrzewionym systemie korzeniowym. W środowisku kwaśnym ( $\mathrm{pH} 4,2$ ) poziom stymulacji wzrostu roślin był mniejszy niż na pożywkach o pH 6,2 , liczba zregenerowanych eksplantantów mniejsza, przy takim samym kierunku różnicowania. 